\title{
The Use and Creation of Myths in Major Works of P. B. Shelley: An Interpretation
}

\author{
${ }^{1}$ Ali Saaleh Ahmed Alhaidari, ${ }^{2}$ Dr. S. G. Bhanegaonkar \\ ${ }^{1}$ Research Scholar, English Dept., School of Languages, Literature and Cultural Studies, SRTM University, \\ Nanded, India. \\ ${ }^{2}$ Associate Professor, Post- Graduate Department of English and Research Centre, People's College, SRTM \\ University, Nanded, India.
}

\begin{abstract}
Mythmaking is the process of endowing nature along with its elements some attributes of human beings and animals. Classic myths and its contents influence a large number of writers and lead them to adopt some of its aspects in their writings. This brief paper is a serious attempt to shed light on the influence of classic myths on some writings of Percy Bysshe Shelley. Besides, it aims at offering a glimpse on how Shelley shifts from borrowing some aspects of myths to create his own mythical wisdom.
\end{abstract}

Key words: myth, mythmaking, mythmaker, spiritualize.

\section{Introduction:}

Right from the beginning of philosophical thinking, some intellectuals as well as some artists start thinking on the role of emotions in human life. However, there was a period of ignoring the emotions and focusing on the reason. Church looks upon the classic myths as a source of paganism. Thus, it uses the classic myths to lead people to the right way. However, these artists and intellectuals do not pay more attention to reason and religion; they are concerned with stories and the way of plotting them. Therefore, they establish a new movement known as romanticism. One of the most apparent features of the Romantic Movement is the freedom of imagination, so all romanticists are dreamers. The classic mythology gives them the early seeds for planting their own imagination. The romantic writers start with exploiting the mythical stories and scenes to be the sources of their works and then they start to make their own myths.

Shelley is one of the greatest romanticists who belong to the second generation of this movement. Because of his early knowledge of the classic myths, he exploits some aspects of them in his works such as mythological themes, names and features of some characters, mythical creatures and some mythical images. Furthermore, he creates his own myths that depend on the principles of creating myths. His own myths are based on the concept of spiritualizing the nature.

\section{The Use of Mythical Themes:}

Shelley applies some mythical themes in his works such as the theme of death, incest, solitude, unrequited love and narcissism. The early death of Adonis in classic myths is the source for one of his long poems in which he laments Keats. The early death of Keats affects Shelley, so he composes an elegy entitled Adonais (1821). He believes that Keats has died because of critics who have attacked his work, Endymion (1818), so he compares them to the bear that kills Adonis, the god of fertility. The goddess of beauty, Aphrodite, laments the death of Adonis, her lover. Similarly, Urania, Adonais's mother mourns for the death of her son. In the poem, the name of Adonais symbolizes Keats. A consolation comes at the end in both stories. In the classic myths, Adonis is eternalized by claiming that his grave produces flowers in the spring every year. On the other side, Shelley portrays Keats as a spiritual force living in the nature forever.

Shelley discusses the theme of incest in some of his works. In fact, incest has its root in classic mythology as well as ancient literary works. Jack David Zipes assures that this issue has a long history in the western literature and culture. He states that this theme "can be clearly traced back to the Greek and Roman myths, in particular to the Antics of the male gods such as Jupiter and Zeus." (Zipes : 218) Classic myths include some myths that focus on this issue; for instance, the myth of Oedipus is one of the most popular stories that talk about a prohibited intercourse between mother and son. The intercourse that has happened between Oedipus and his mother is unwitting. Thus, the revelation of the truth leads to tragic ends for both Oedipus and his mother. His mother hangs herself as soon as she knows the fact. After finding her dead, Oedipus pulls the pins of the robe and stabs out his eyes. Eventually, he asks for exiling from the kingdom. Likewise, Shelley uses the unwitting incestuous love along with the tragic end in the poem Rosalind and Helen. Like the myth of Oedipus, the hidden fact appears after committing incest. Shelley adapts the myth to be between a half-brother and a sister. The story has a tragic end as similar as the myth. Rosalind's brother falls dead when he hears that 
he has been in love with his sister. On the other hand, Rosalind has been shocked, and her heart becomes stone like. After her father and second husband's death, she has never felt sorrow for them. She explains her situation:

I did not weep: I did not speak:

But day by day, week after week,

I walked about like a corpse alive

Alas! sweet friend, you must believe

This heart is stone: it did not break.

(Shelley, The Works of Percy Bysshe Shelley : 209)

The influence of classic myths on Shelley leads him to produce a work that has some similarities with another myth. He produces a novel entitled Zastrozzi (1810) that discusses the incest between a father and his daughter. The myth of Myrrah is another story about a sexual relation between a daughter and a father. In this novel, the father rapes his daughter. The daughter has attempted her best to get revenge by killing him. In the myth of Myrrah, Aphrodite urges Myrrah to commit incest with her father. Myrrah has done that with the assistance of her nurse. When her father knows the fact, he pursues her with a knife to kill her. However, Aphrodite turns her into a myrrh tree. Myrrah gives a birth to Adonis whose early death inspires Shelley to write an elegy on the death of Keats. The themes of incest and revenge dominate both the myth and the novel.

Shelley uses all his knowledge to suit his poetic and politic aims. He produces another poem that contains incestuous relation between a brother and a sister in the first version of the poem, Laon and Cythna (1818). However, the publishers reject to publish it because of "the incest theme along with some of the more extreme radicalism and atheism." (Leask : 110) After adapting, it is entitled as The revolt of Islam.

In classic myths, the mythologizers create stories that discuss the theme of solitude as well as the theme of narcissism. The myth of vengeful demon that drives his victims into deserted places inspires Shelley to produce a poem entitled Alastor after the name of that demon. In American Heritage dictionary, Soukhanov refers to 'Alastor' as "an avenging deity or spirit, the masculine personification of Nemesis, frequently evoked in Greek tragedy." (Soukhanov :..) Shelley does not talk about solitude of Physics, but he discusses the solitude of spirit that may derive the soul to create its own world. The poem shows some allusions of the myth of Narcissus. Stuart M. Sperry states, "The myth that informs Alastor is its close correlative, the story of Narcissus and his love for his own reflection." (Sperry 21) In fact, the poem shares the myth many similarities such as the theme of solitude. In his thesis, Narcissus Englished a Study of the Book of Thel, Alastor, and Endymion, Bernhard David Harder explains the allusions of the myth of Narcissus in Alastor. In his explanation, He refers to the correspondence of leaving societies and homes in the sake of wandering. Whereas Narcissus leaves his society for wandering and hunting, the poet in the poem leaves home for seeking for the truth. Harder concludes that the poet's leaving of home corresponds to Narcissus' seclusion of society.

In fact, the poem contains some mythical features. One of the themes that characterize the myth is the unmistaken search for shadow. Instead of looking for truth and beauty, the poet pursues the shadow of truth that is in his deep mind only. Likewise, Narcissus pursues his shadow to fall in love with it instead of falling in love with Echo. The poet becomes the pursued and the pursuer, and Narcissus becomes "the worshipped and the worshipper." (Ovid : 77) The theme of unrequited love is another theme that has taken place in both stories. In the myth, Echo loves Narcissus who rejects her love. Similarly, Arabian maiden loves the poet who rejects her, as well. Because of Narcissus and the poet's rejection, maiden and Echo are doomed to gaze them only. The maiden gazes him through tears, and Echo gazes from afar. Besides, the poem includes some images that are only as an echo of the images of the myth. For example, the poem and the myth have introduced the same images of virgins who waste ways for love as well as the wild eyes of youth.

\section{The Use of Mythical Characters}

In the art of characterization, Shelley shows extraordinary talent in exploiting of classic myths in his works. Hence, several characters are only shadows of some mythological characters with whom they share names and some features. Therefore, the influence of classic myths is widespread on his works. It is like a fountain that adds him pure water - plots for stories and names and features for characters. Shelley's Adonais is based on the myth of Adonis. Shelley applies the premature death of Adonis along with his name and features to be the features of his poem. The name of his hero, Adonais, is derived out of the name of a mythological character, Adonis, who is a beautiful mortal youth. Shelley composes his poem to mourn the premature death of his friend, Keats. He transmutes Keats to be a beautiful youth. Shelley grants his Adonais the eternality as Adonis in which he regards him as a spirit united with nature. Like classic myth, Shelley provides his poem with a female mourning the death of the hero as the myth. He names the heroine, Urania. Shelley derives the name from the name of Aphrodite Urania, the goddess of heavenly love.

Many other poems and plays have characters named and featured after mythological characters. In his play, Prometheus Unbound, the characters - Jupiter, Apollo, Mercury, Asia...etc- have names and features of classic myths. Shelley has used the myth to fulfill a politic aim. 
Most classic myths are interwoven around supernatural elements such as gods, goddesses, demigods, spirits, nymphs, ghosts and mythical creatures. Shelley has knowledge of such facts, so he employs many of these elements in his works. Furthermore, he, as a mythmaker, creates his own supernatural elements. Apollo is one of Olympian gods, and he is the only god that appears with the same name in both Greek and Roman mythologies. $\mathrm{He}$ is attributed as

The god of poetry, music, archery, prophecy, and healing. Associated with the care of herds and crops, Apollo was a sun god of great antiquity, yet he is represented as an ever-youthful god, just and wise and of great beauty. (Daly : 12)

Shelley introduced Apollo in some of his works such as Prometheus Unbound (1819). Moreover, he composes a poem entitled as Hymn of Apollo (1820). Shelley writes the poem in a first person singular and makes Apollo the narrator. Apollo, in this poem, is the main character who explains how he gives life to the earth and provides its elements with various colors. At the end of the poem, Apollo depicts himself as:

I am the eye with which the Universe

Beholds itself and knows itself divine;

All harmony of instrument or verse,

All prophecy, all medicine are mine,

All light of art or nature;

(Shelley, The selected Poetry and Prose of Shelley : 464)

Pan is another old Greek god who emerges in the works of Shelley. Pan is a god of "herds and flocks, fertility, forests, and wildlife." (Daly : 98) However, his appearance differs from other gods. He has a half body of man and a half of goat. In one of the ancient myth, Pan has a competition with Apollo, the god of music. Shelley illustrates the competition between them and produces two hymns, Hymn of Apollo and Hymn of Pan (1820). In each one of them, the god is the narrator who attempts to win the competitions by explaining his role in creating the world.

Gods and goddesses are not the only characters depicted in Shelley's works. The fairies and nymphs also play roles in his works either plays or poems. The myths of fairies inspire him to interweave his own stories of fairies. His long poem, Queen Mab (1818), is a fairy tale that shows the future of Shelley's Utopia. The main character of the poem is a fairy that moves on a chariot. The human female character of the poem has a mythological name, Ianthe. In fact, human beings are incapable to see the fairies. Therefore, Shelley produces the dream as a medium between the real world and the supernatural world. After Ianthe falls asleep on a couch, the fairy, Queen Mab, appears in her dream and gets her soul to show her the future.

The spirits and ghosts have taken place in the writings of Shelley. He uses the ghosts and spirits to explain the possibility of getting a glimpse of a world hidden beyond the real world. In his poem, Hymn to Intellectual Beauty (1816), he depicts a boy seeking for ghosts in order to get a clear illustration of the unseen world. Shelley refers to the places that the ghosts may live in such as empty rooms, caves, ruins and forests. In such places, he summons the ghosts and spirits with the phrases that he believes that will compel them to appear, but they do not appear. The boy, at the end, feels the existence of the spirit of the beauty. Shelley denies the existence of ghosts in these places to glorify the spirit of Beauty. He, however, introduces another idea about the existence of the ghost In Mont Blanc. The speaker encounters ghosts as well as shadows of real natural objects in the cave of a witch.

Shelley believes in the existence of the spirits in nature. Therefore, he spiritualizes all its elements. He gives spirits to night, autumn, wind...etc. He discusses their power on each other in various works. For instance, in his poem Ode to the West Wind (1819), he discusses the power of the wind as "destroyer and preserver." (Shelley, Ode to the West Wind and Other Poems : 35) Besides, he declares at the end of Adonais that Keats's spirit makes an eternal union with the nature.

Black art along with the hidden power of witches is a part of the supernatural world. Shelley writes poems that include a witch as a character and writes poems that refer to her residence. His witch is not like others' witches. They have some attributes that present them in a different form than others. His witch has divine roots as well as stunning beauty. Besides, she does not possess the innate power to do evil as a traditional witch. His poem, The Witch of Atlas (1820), is about a witch who resides on Atlas Mountains. The impact of classic myths apparently appears in the poem. In the introduction of the poem, the poet mentions that the witch's mother is "one of the Atlantides" and Apollo. In Greek mythology, "Atlantides was name given to the Pleiades who were fabled to be the seven daughters of Atlas." (Chopra : 41) The poet recounts how the beauty of the mother attracts the god of the sun. He respectively changes her into a vapor, a cloud, and then a meteor. Eventually, he changes her into "One of these mysterious stars /which hide themselves between the Earth and Mars." (P. B. Shelley, The Works of Percy Bysshe Shelley : 269)

Shelley does not portray the witch as an old woman who has an ugly face and has vicious aims of destroying the world. Instead, he depicts her as a lovely and gentle woman with power that makes all the beasts of every kind come to her asking for curing their vicious habits. Shelley illustrates her as: 


\begin{abstract}
A lovely lady garmented in light
From her own beauty--deep her eyes, as are

Two openings of unfathomable night

Seen through a Temple's cloven roof--her hair

Dark--the dim brain whirls dizzy with delight

Picturing her form; her soft smiles shone afar,

And her low voice was heard like love, and drew

All living things towards this wonder new.
\end{abstract}

(P. B. Shelley, The Works of Percy Bysshe Shelley : 269)

\title{
IV. The Use of Mythical Images
}

Each writer or speaker is capable to use his own language skillfully to achieve his aim. On other words, language is a game in which writers and speakers use to pursue another person and fulfill an aim. For instance, a dreamer is interested in either unreal world or planning a real future world. Therefore, he illustrates mental image for unreal world by using some words and phrases to affect the minds of others. In his essay, A Defence of Poetry (1821), Shelley states that poetry "may be defined to be 'the expression of imagination."' (Shelley : 635) According to him, the association between past, present and future is the work of imagination. Thus, as a dreamer and an imaginationist, Shelley attempts to produce a clear image about his fictional world in which he mingles the world of spirits with real world to introduce his Utopia.

Shelley borrows some mythical images and uses them in his poems and plays. In Ode to the West Wind, the traditional mythological association of death and winter has taken place in the first stanza. Shelley refers to the association of autumn and diseases that preceded the death, as well. He portrays the moving of the rotten leaves like the fleeing of the ghosts from enchanters.

He uses some images of mythological gods and goddesses in his works. In Adonais, he compares Byron to Apollo:

\section{........like Apollo, from his golden bow, \\ The Pythian of the age one arrow sped \\ 'And smiled! (Shelley, Adonais : 50)}

Here, Shelley refers to the image of Apollo whose appearance is always portrayed bearing a bow and arrows. On the other hand, he mentions the name "pythian" that is the name of Apollo for killing a chthonic serpent python. In this image, Shelley portrays the critics who criticize Keats and cause his death as Pythia, the monstrous serpent, and Byron as Apollo. Those critics attempt to criticize Byron; however, Byron replies with a short poem that leads them to keep silence forever. Byron's short poem resembles Apollo's arrow that kills Pythia. Like Apollo, Byron smiles confidently and throws his weapon to kill the monstrous creatures. Shelley also compares himself to Actaeon, a Greek hunter. In mythology, while hunting in the forest, Actaeon has seen Diana, the goddess of beauty, bathing in a hidden brook. The goddess becomes angry of seeing her naked, so she changes him to a stag. After that, his hounds have come and torn him into pieces.

$$
\text { ...he, as I guess, }
$$

Had gazed on Nature's naked loveliness,

Actaeon-like, and now he fled astray

With feeble steps o'er the world's wilderness,

And his own thoughts, along that rugged way,

Pursued, like raging hounds, their father and their prey.

(Shelley, Adonais : 51)

In this comparison, Shelley states that he has seen the naked loveliness of nature as Actaeon sees the naked beauty of Diana. Actaeon runs away after seeing Diana and changing into a stag. Similarly, Shelley reports that after getting a glimpse to the naked loveliness of nature, he runs away over the world. In fact, he travels to Italy, Switzerland and other countries. Shelley looks upon his thoughts as Actaeon's hounds in which they pursue him and tear him into pieces.

Shelley mentions some mythical creatures that have strange appearance as Pan in more than a poem or a play. In The Witch of Atlas, he refers to Polyphemes and Cyclopses that have the same appearance. They are giants with one eye in the middle of the head. Centaur is a mythical creature whose body is half-man and half horse. He refers to other strange creatures that their bodies unite two different beings such as Satyrs, Dogheaded, bosom-eyed, and bird-footed. Shelley creates another mythical creature that is as similar as mythical Greek creature. The witch of Atlas has used a 'strange art' to create Hermaphrodite. She kneads the ice and fire for creating this creature. It has wings and has the feature of males and females, so it is sexless. In Greek mythology, Hermes and Aphrodite are the parents of Hermaphrodite. The witch creates Hermaphrodite to be her companion and servant. 
The medieval Christian mythology is also reflected in the works of Shelley. The myth of The Wondering Jew that takes place in the middle ages is about a Jew named Ahasuerus, who works as a shoemaker. Ahasuerus talks to the Christ jeeringly when he stops to get a rest beside his home. As a result, the Christ curses him to wander around the earth until the second coming. Shelley refers to that event by the hero of his poem, The Wandering of Jew that recounts the suffering of the Jew. Paul narrates his story of jeering Christ:

\author{
I mocked our savior, and I cried, \\ Go, go, "Ah! I will go!" said he, \\ "Where Scenes of endless bliss invite; \\ To the blest regions of the light \\ I go, but thou shalt here remain,- \\ Thou diest not till I come Again, "-
}

(P. B. Shelley, The Wandering Jew : 28)

In this poem, Shelley presents a mediator between the wandering Jew and Christ to end the suffering of the former. Shelley mentions this myth along with its hero in more than one work. In Queen Mab, Ahasuerus is one of the most essential characters, and Shelley refers to him in Hellas, as well. In these detached works, Shelley portrays Ahasuerus with some differences. Whereas he is depicted as a zealot Queen Mab, he gets the traits of a wise man in Hellas. However, in both works, Ahasuerus believes in the idea of revolution.

\title{
V. The Creation of Myths
}

The classic writers have created myths by providing nature with the power to do the same deeds and actions that human beings and animals do. Therefore, Shelley does not rely on others' creativity totally, but he transcends to create his own myths by following the same procedures of creating their stories. According to him, myth is a fictitious narrative incarnating an idea on natural phenomena. In mythology, the primitives believe that the sun god rides the chariot of the sun from the morning until night. The movement of the sun follows the tracks of dawn and night that vanish after each position the light of the sun reaches. Seasons appear as powerful beings that overcome each other regularly in the year. On this basis, Shelley moves forward to mythologize the components of nature by creating new myths out of the natural forces. He ignores the belief that the nature as one being and he alternatively believes that each natural phenomena is a detached being has its own life and power. Thus, he mythologizes the cloud, the night, the west wind and the moon.

In his poem The Cloud (1820), Shelley does not only deal with it as a physical substance but also as an immortal minor divinity. He endows it the features of nymphs in classic mythology. On the other hand, its ability to change its form makes it eternal. Thus, the death is improbable to happen. Shelley refers to the various forms that the cloud seems in. Shelley looks upon the cloud as a living being, so he portraits it with various images that connect to other beings. The early images have some resemblance with some activities that human beings do. The poet impersonates the cloud as a gardener watering flowers. In another image, it is as a mother provides "light shade" for her child from the sun when he takes a nap. In the later images, he depicts the cloud as a bird that has wings, and it moves its wings to drop down the dew on "the sweet buds". The poem is full of images that mirror Shelley's genius as a mythmaker. In spite of that, Shelley creates his myths imaginatively; he does not ignore the scientific truths. On other words, he uses the scientific truths along with imagination to be sources to his myth. In the poem, he refers to the rotation of the earth around the sun when he depicts the dance of the cloud "about the sun". Shelley's knowledge of science appears again in his reference to the fact that the cloud changes. Its change includes the change of shape, size and color.

Shelley produces some other poems in which he mythologizes some natural phenomena. To Night (1821), To a Skylark (1820), Ode to the West Wind and To The Moon (1820) are other illustrations of his mythmaking power. In the process of personifying the natural phenomena to be myths, Shelley depicts them in such a plausible way that they never lose their true features. According to him, the west wind, night, moon, skylark and cloud remain natural elements, so they retain their own features. The scientific truths remain the basis for his description of these phenomena. In his description of the west wind, Shelley refers to scientific truth that wind moving the rotten leaves from one place to another and then these leaves become seeds for growing other trees. To conclude, the classic myths influence Shelley's thoughts that lead him composing works with mythical features. These features are diverse such as themes, names and traits of some characters and supernatural elements. Besides, his mythical power is due to the deep understanding of the basis of the creation of classic myths. Therefore, most of his works include some mythical features either classically or creatively.

\section{References}

[1] Chopra, Ramesh, ed. Academic Dictionary of Mythology. delhi: Isha Books, 2005.

[2] Daly, Kathleen N., Marian Regel, ed. Greek and Roman Mythology A to Z. New York: Facts on File, 2004.

[3] Harder, Bernahard David. Narcissus Englished a Study of the Book of Thel, Alastor, and Endymion. Diss. Vancouver: University of British Columbia, 1966

[4] Leask, Nigel. British Romantic Writers and the East: Anxieties of Empire. Cambridge: Cambridge University Press, 1992. 
[5] Ovid. Ovid: The Metamorphoses. Trans. Horace Gregory. New York: The viking Press, 1958.

[6] Shelley, Percy Bysshe. Adonais. Ed. William Michael Rossetti. Teddington: The Echo Library, 2006.

[7] —. The Works of Percy Bysshe Shelley. Ed. Mary Shelley. Paris: A. \& W. Galingani \& Co., 1830

[8] —. The selected Poetry and Prose of Shelley. Hertfordshire: Wordsworth Edition Limited, 2002.

[9] —. The Wandering Jew. Ed. Bertram Dobell. London: Reeves and Turners, 1887.

[10] Soukhanov, Anne H., ed. The American Heritage Dictionary of the English Language. Jonathan P. Latimer, n.d.

[11] Sperry, Stuart M. Shelley's Major Verse: The Narraive and Dramatic Poetry. Cambridge : Harvard University Press, 1988.

[12] Zipes, Jack David. The Enchanted Screen: The Unknown History of Fairy-Tale Films. New York: Routledg, 2011.

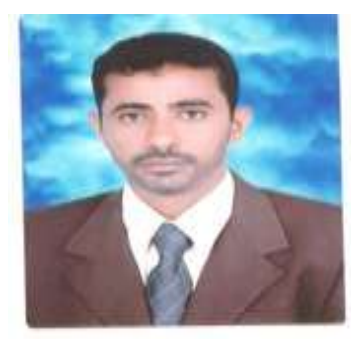

\section{Ali Saaleh Ahmed Alhaidari}

Research Scholar, English Dept., School of Languages, Literature and Cultural Studies, SRTM University, Nanded, India.

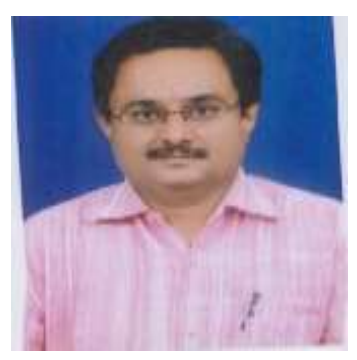

\section{Dr. S. G. Bhanegaonkar}

Associate Professor, Post- Graduate Department of English and Research Centre, People's College, SRTM University, Nanded, India. 